\title{
Biodegradation of Polycyclic Aromatic Hydrocarbons by Associated Microbes from Abattoir Wastes in the Niger Delta, Nigeria
}

\author{
Ogbonna D. $\mathbf{N}^{1}$, Ide riah T. J. K. ${ }^{2, *}$, Nwachukwu M. I. ${ }^{3}$ \\ ${ }^{1}$ Department of Applied and Environmental Biology, Rivers State University of Science and Technology, Nkpolu-Oroworukwo, PMB \\ 5080, Port Harcourt, Nigeria \\ ${ }^{2}$ Institute of Pollution Studies, Rivers State University of Science and Technology, Nkpolu-Oroworukwo, PMB 5080, Port Harcourt, \\ Nigeria \\ ${ }^{3}$ Department of Microbiology, Imo State University, Owerri
}

\begin{abstract}
The biodegradation of polycyclic aro matic hydrocarbons by associated mic roorganisms were studied. Soil and waste water samp les were collected from four abattoirs located at Egbu and Ogbe in Imo state, Trans-Amadi and Ahoada in Rivers State. Likewise, surface water and sediment samples from Otamiri River and Og inigba Creek adjoined to Egbu and Trans-Amadi abattoirs, respectively were collected using standard methods. The ability of hydrocarbon utilizing bacteria and fungi to biodegrade polycyclic aromatic hydrocarbons (PAHs) was carried out by growing isolates in a mineral salt broth amended with PAHs. Levels of polycyclic aro matic hydrocarbons (PAHs) left after incubation were determined using Gas chromatographic method. Results showed that soil samples from various abattoirs had high concentration of PAHs which ranged from $0.176 \mathrm{mg} / \mathrm{kg}$ from Ahoada abattoir to $2.44 \mathrm{mg} / \mathrm{kg}$ fro $\mathrm{m}$ Egbu abattoir. In a 21-day biodegradation test, there was a drop in the initial concentration of PAHs used as control from $0.03 \mathrm{mg} / \mathrm{l}$ to $0.024 \mathrm{mg} / \mathrm{l}$. Test results showed decrease in the concentration of PAHs with increase in exposure time. There was observable loss of low molecular weight PAHs than the high molecular weight components. It is evident from the study that both mixed cultures of bacteria and fungi can biodegrade polycyclic aromatic hydrocarbons. Results from this study have shown that abattoir wastes have high pollution strength and thus should be treated before being discharged into the environment. Thus bacteria and fungi isolated from and within the abattoirs are potential agents of remedying environments impacted by polycyclic aromatic hydrocarbons (PAHs).
\end{abstract}

Keywords Abattoir, Biodegradation, Polycyclic Aromatic Hydrocarbons, Pollution, Microorganisms

\section{Introduction}

Microbial degradation contributes significantly to the ultimate removal of organic molecules including oil from soil, freshwater, brackish water and marine environments [1]. Various reports have shown that degradation or biotransformation of pollutants is not limited to the activity of a few versatile microorganisms, it occurs widely within bacteria[2], mycelia fungi[3], and yeasts[4],[5]. Various bacteria, mycelial fungi and yeasts are involved in the biodegradation of crude oil

PAH molecule stability and hydrophobicity are two primary factors that contribute to the persistence of high molecular weight PAHs in the environment[6]. However, acceleration of their biodegradation process can be achieved

* Corresponding author: itubonimi@yahoo.com (Ideriah T. J. K.)

Published online at http://journal.sapub.org/microbiology

Copyright (C) 2012 Scientific \& Academic Publishing. All Rights Reserved by manipulating the substrate microenvironment, such as adding nutrients, enhancing aerobic status, introducing microbial inoculums or enhancing PAH bioavailability[7] -[9]. Microbial degradation represents the major method responsible for the ecological recovery of $\mathrm{PAH}-$ contaminat ed sites[10],[11]. However, the success of bioremediation projects has been limited by the failure to remove high molecular weight PAHs[12]. The recalcitrance of high molecular weight PAHs to microbial degradation has led to recent research focus on evaluating a wide phylogenetic spectrum of microorganisms for the degradation of these compounds[12].

The decontamination of PAH-polluted sites is of major importance because many PAH compounds are either known or suspected carcinogens and mutagens[12]. Most low molecular weight PAHs are biodegradable in the presence of suitable microbial populations and a number of bioremediation programs have had some success in the decontamination of PAH - contaminated sites[10]. However, the extent and rate of PAH biodegradation are 
restricted by the limited bioavailability of these compounds, which is due to their low aqueous solubilities and strong adsorptive capacity to soil and sediments[13]. In addition to these are lack of nutrients and scarcity of PAH biodegrading microorganisms[14]. Coupled with this, they are thermodynamically stable since they are derivatives of the benzene ring with large negative resonance energies [15].Though low molecular weight PAHs are biodegradable, high - ring - number PAHs are difficult to biodegrade[15]. This is because the environmental fate of a PAH particle is dependent in part on both its molecular size i.e. the number of aro matic rings and pattern of ring lin kages. Generally, an increase in the size and angularity of a PAH molecule results in a concomitant increase in hydrophobicity and electrochemical stability[16].

Little is known about the biodegradation of mixtures of PAHs especially the effect of one PAH component on the biodegradation of another[15]. However, there has been increased interest in developing and understanding of microbial degradation process when PAHs are present in complex mixtures. A mixture of contaminants in a bioremediation system may result in inhibition, co-metabolism, augmentation or no effect at all[17]. For instance, both inhibition and co-metabolism have been observed in the degradation of a simple mixture of phenanthrene and fluorantene by a Pseudomonas sp[18]. Previous studies of PAH degradation by mixed and pure cultures presented evidence that there are interactions between PAHs in mixtures that influence biodegradation, for example, exposure of marine sediments to one PAH was observed to enhance degradation of other subsequently added PAHs [19]. Mixed microbial populations from marine waters sequentially mineralized naphthalene, phenanthrene and anthracene suggesting preferential utilization of substrates by a general PAH - degrading population[20]. Sequential removal of PAHs has also been demonstrated in batch incubations where recalcitrant PAHs were removed truly after more labile PAHs were degraded[21]. According to[22] higher - molecular we ight PAHs were more resistant to biotransformation when present as pure compounds in soil than when present in complex waste mixtures in soil, whereas lower molecular weight PAHs were transformed more rapidly as pure compounds.

Hydrocarbon biodegradation in terrestrial ecosystems may be limited by the available water for the microbial growth and metabolis $\mathrm{m}[23]$. In a study[24] of oil sludge degradation in soil, reported optimal rates of biodegradation at 30 to $90 \%$ water saturation. The failure according to[24] to observe inhibition of degradation at the lower values was ascribed to a hydrocarbon - mediated reduction in the water - holding capacity of the soil. The process of biodegradation depends on certain microorganis ms such as bacteria, yeast and moulds [25]. This breakdown of organic compounds by microorganisms particularly bacteria is responsible for the decomposition of both natural and synthetic organic compounds in nature[25]. Compounds that are readily biodegradable are generally utilized as growth substrates by simple microorganisms. Many of the components of petroleum products and frequent groundwater contaminants such as benzene, toluene, ethyl benzene and xylene are utilized by many genera of bacteria as sole carbon sources for growth and energy[25].

Abattoir activities, such as burning of bones and skin with tyres, woods or coal, lead to the emission of smoke and gases to the atmosphere, causing air pollution[15]. This aspect of abattoir activity can also introduce chemical pollutants such as polycyclic aromatic hydrocarbons (PAHs) to the environment[15]. As a result of inadequate waste treatment facilities, wastes from abattoir are deposited on the land or channeled into water resource leading to pollution. Due to the carcinogenic, mutagenic and teratogenic nature of PAHs[15], there is need to eliminate them from the environ ment.

This study therefore aims to determine the ability of microorganis ms (bacteria and fungi) isolated from samples contaminated by abattoir wastes to biodegrade PAHs and develop microbial inocula to enhance the biodegradation of contaminating polycyclic aro matic hydrocarbons (PAHs).

\section{Materials and Methods}

\subsection{Study Area}

The study was carried out in abattoirs located at Ogbe and Egbu in Imo State, Trans-Amadi in Port Harcourt and Ahoada both in Rivers State. Ogbe lies on longitude $05^{\circ}$ $31.965^{\prime}-05^{\circ} 32.890^{\prime} \mathrm{N}$ and latitude $007^{\circ} 15.695^{\prime}-007^{\circ}$ $18.010^{\prime} \mathrm{E}$, while Egbu lies within longitude $05^{\circ} 28.432^{\prime}-05^{\circ}$ $29.802^{\prime} \mathrm{N}$ and latitude $007^{\circ} 03.200^{\prime}-007^{\circ} 04.215^{\prime} \mathrm{E}$. These areas have a tropical climate. The average re lative hu midity is about $80 \%$. The inhabitants of the areas are mainly farmers, civil servants, petty traders and casual workers.

Port Harcourt is located on longitude $4^{\circ} 48.442^{\prime}-4^{\circ}$ $49.444^{\prime} \mathrm{N}$ and latitude $007^{\circ} 02.303^{\prime}-007^{\circ} 03.545^{\prime} \mathrm{E}$. The climate of Port Harcourt falls within the sub equatorial climate belt. Temperature and humidity are high throughout the year. The area is marked by two distinct seasons, the wet seas on and the dry season, with $70 \%$ of the annual rain fall between April and August, while 22\% is spread in the three months of September to November. However, the driest months are from December to March. Ahoada is located on longitude $4^{\circ} 28.222^{\prime}-4^{\circ} 50.111^{\prime} \mathrm{N}$ and latitude $006^{\circ} 43.122^{\prime}-007^{\circ} 04.225^{\prime} \mathrm{E}$. The inhabitants of the area are mainly civil servants, traders and farmers.

\subsection{Identification of Sampling Points}

A total of thirty six (36) sampling points were selected for the study (Table 1).

\subsection{Che mic als and Reagents}


Table 1. Identification of Sampling stations, points, coordinates and sample types in the study areas

\begin{tabular}{|c|c|c|c|c|}
\hline \multirow{2}{*}{$\begin{array}{l}\text { Sampling } \\
\text { Stations }\end{array}$} & \multirow{2}{*}{$\begin{array}{l}\text { Sampling } \\
\text { Points }\end{array}$} & \multicolumn{2}{|c|}{ Sampling point Co-ordinates } & \multirow[t]{2}{*}{ Types of Samples } \\
\hline & & Northing (N) & Easting (E) & \\
\hline \multirow{4}{*}{ Ogbe Abattoir I } & $\mathrm{A}$ & $05^{\circ} 31.965^{\prime}$ & $007^{\circ} 16.901^{\prime}$ & Soil (Test sample) \\
\hline & B & $05^{\circ} 32.800^{\prime}$ & $007^{\circ} 15.800^{\prime}$ & Soil (Test sample) \\
\hline & $\mathrm{C}$ & $05^{\circ} 32.890^{\prime}$ & $007^{\circ} 15.695^{\prime}$ & Soil (Test sample) \\
\hline & $\mathrm{D}$ & $05^{\circ} 32.065^{\prime}$ & $007^{\circ} 17.001^{\prime}$ & Soil (Control) \\
\hline \multirow{4}{*}{ Ogbe Abattoir II } & $\mathrm{A}$ & $05^{\circ} 31.884^{\prime}$ & $007^{\circ} 6.964^{\prime}$ & Waste water \\
\hline & B & $05^{\circ} 31.665^{\prime}$ & $007^{\circ} 16.335^{\prime}$ & Waste water \\
\hline & $\mathrm{C}$ & $05^{\circ} 31.578^{\prime}$ & $007^{\circ} 16.315^{\prime}$ & Waste water \\
\hline & $\mathrm{D}$ & $05^{\circ} 33.000^{\prime}$ & $007^{\circ} 18.010^{\prime}$ & Waste water \\
\hline \multirow{4}{*}{ Egbu Abattoir I } & $\mathrm{A}$ & $05^{\circ} 28.432^{\prime}$ & $007^{\circ} 03.200^{\prime}$ & Soil (Test sample) \\
\hline & $\mathrm{B}$ & $05^{\circ} 28.441^{\prime}$ & $007^{\circ} 03.209^{\prime}$ & Soil (Test sample) \\
\hline & $\mathrm{C}$ & $05^{\circ} 28.582^{\prime}$ & $007^{\circ} 03.312^{\prime}$ & Soil (T est sample) \\
\hline & $\mathrm{D}$ & $05^{\circ} 28.559^{\prime}$ & $007^{\circ} 3.231^{\prime}$ & Soil (Control sample) \\
\hline \multirow{4}{*}{ Egbu Abattoir II } & $\mathrm{A}$ & $05^{\circ} 29.651^{\prime}$ & $007^{\circ} 04.205^{\prime}$ & Waste water \\
\hline & $\mathrm{B}$ & $05^{\circ} 29.668^{\prime}$ & $007^{\circ} 04.215^{\prime}$ & Waste water \\
\hline & $\mathrm{C}$ & $05^{\circ} 29.705^{\prime}$ & $007^{\circ} 04.285^{\prime}$ & Waste water \\
\hline & $\mathrm{D}$ & $05^{\circ} 29.802^{\prime}$ & $007^{\circ} 04.918^{\prime}$ & Waste water \\
\hline \multirow{2}{*}{ Otamiri river } & A & $05^{\circ} 28.426^{\prime}$ & $007^{\circ} 03.179^{\prime}$ & $\begin{array}{l}\text { Surface water and Sediment } \\
\text { (Test Samples) }\end{array}$ \\
\hline & B & $05^{\circ} 27.423^{\prime}$ & $007^{\circ} 04.156^{\prime}$ & $\begin{array}{c}\text { Surface water and Sediment } \\
\text { (Control samples) }\end{array}$ \\
\hline \multirow{4}{*}{ Trans-Amadi Abattoir I } & $\mathrm{A}$ & $04^{\circ} 48.886^{\prime}$ & $007^{\circ} 2.707^{\prime}$ & Soil (T est sample) \\
\hline & $\mathrm{B}$ & $04^{\circ} 48.782^{\prime}$ & $007^{\circ} 2.608^{\prime}$ & Soil (Test sample) \\
\hline & $\mathrm{C}$ & $04^{\circ} 48.615^{\prime}$ & $007^{\circ} 2.405^{\prime}$ & Soil (Test sample) \\
\hline & $\mathrm{D}$ & $04^{\circ} 48.442^{\prime}$ & $007^{\circ} 2.303^{\prime}$ & Soil (Control sample) \\
\hline \multirow{4}{*}{ Trans- Amadi abattoir II } & $\mathrm{A}$ & $04^{\circ} 49.789^{\prime}$ & $007^{\circ} 03.801^{\prime}$ & Waste water \\
\hline & $\mathrm{B}$ & $04^{\circ} 49.628^{\prime}$ & $007^{\circ} 03.702^{\prime}$ & Waste water \\
\hline & $\mathrm{C}$ & $04^{\circ} 49.522^{\prime}$ & $007^{\circ} 03.665^{\prime}$ & Waste water \\
\hline & $\mathrm{D}$ & $04^{\circ} 49.444^{\prime}$ & $007^{\circ} 03.545^{\prime}$ & Waste water \\
\hline \multirow{2}{*}{ Oginigba Creek } & A & $04^{\circ} 50^{\prime} 001^{\prime \prime}$ & $007^{\circ} 04^{\prime} 425^{\prime \prime}$ & $\begin{array}{c}\text { Surface water and Sediment } \\
\text { (Test Samples) }\end{array}$ \\
\hline & B & $04^{\circ} 50^{\prime} 111^{\prime \prime}$ & $007^{\circ} 04^{\prime} 225^{\prime \prime}$ & $\begin{array}{c}\text { Surface water and Sediment } \\
\text { (Control samples) }\end{array}$ \\
\hline \multirow{4}{*}{ Ahoada abattoir I } & $\mathrm{A}$ & $04^{\circ} 40^{\prime} 126^{\prime \prime}$ & $006^{\circ} 45^{\prime} 278^{\prime \prime}$ & Soil (T est sample) \\
\hline & $\mathrm{B}$ & $04^{\circ} 39^{\prime} 101^{\prime \prime}$ & $006^{\circ} 44^{\prime} 118^{\prime \prime}$ & Soil (Test sample) \\
\hline & $\mathrm{C}$ & $04^{\circ} 28^{\prime} 222^{\prime \prime}$ & $006^{\circ} 43^{\prime} 122^{\prime \prime}$ & Soil (Test sample) \\
\hline & $\mathrm{D}$ & $04^{\circ} 30^{\prime} 750^{\prime \prime}$ & $006^{\circ} 42^{\prime} 101^{\prime \prime}$ & Soil (Control Sample) \\
\hline \multirow{4}{*}{ Ahoada abattoir II } & $\mathrm{A}$ & $04^{\circ} 40^{\prime} 278^{\prime \prime}$ & $006^{\circ} 44^{\prime} 216^{\prime \prime}$ & Waste water \\
\hline & $\mathrm{B}$ & $04^{\circ} 32^{\prime} 201^{\prime \prime}$ & $006^{\circ} 44^{\prime} 003^{\prime \prime}$ & Waste water \\
\hline & $\mathrm{C}$ & $04^{\circ} 35^{\prime} 002^{\prime \prime}$ & $006^{\circ} 43^{\prime} 100^{\prime \prime}$ & Waste water \\
\hline & $\mathrm{D}$ & $04^{\circ} 31^{\prime} 650^{\prime \prime}$ & $006^{\circ} 41^{\prime} 222^{\prime \prime}$ & Waste water \\
\hline
\end{tabular}

Crude oil (Bonny light) was obtained from Shell Petroleum Development Company Port Harcourt, Nigeria. Polyaromatic hydrocarbons were purchased from Sigma Chemical Company (St Louis, MO). Other solvents and chemicals were obtained in analytical grade from $\mathrm{BDH}$ laboratory supplies (Poole, England). Bacteriological media including potato dextrose agar, nutrient agar, nutrient broth, beef extract agar, MacConkey agar, Salmonella-Shigella agar, etc were purchased from oxoid (Uni-path Ltd., Hampshire, England).

\subsection{Collection of Samples}

\subsubsection{Soil Samples}

Surface soil samples were collected from four different sampling points coded A, B, C and D from a depth of $0-15 \mathrm{~cm}$ using soil auger. About $500 \mathrm{~g}$ of bulked composite soil samples from soil samples collected from points A, B and $\mathrm{C}$ was prepared using the method of[26]. Soil sample from point $\mathrm{D}$, which is about $400 \mathrm{~m}$ from Ogbe, Egbu, Ahoada and Trans Amadi abattoirs served as control sample. 
The soil samples were collected into labelled polyethylene bags and transported to the laboratory in a cooler packed with ice blocks for analysis.

\subsubsection{Water Samp les}

Surface water samples were collected using the method of[27]. The collection was carried out using 4.0litre plastic bottles previously sterilized with $70 \%$ alcohol 24 hours before the final collection. The bottles were rinsed 3 to 4 times with the water sample before the final collection. The water samples were collected along the course of the river at two different points coded A and B. Point A is the immed iate point of discharge of the abattoir wastes into the river, Point $B$ is about $400 \mathrm{~m}$ upstream from Point $A$. The sample from point A served as the test sample while that from point B served as the control sample. To collect the water sample, base of the sterilized sample bottle was held with one hand, the bottle was plunged about $30 \mathrm{~cm}$ below the water surface with the mouth of the sample bottles positioned in an opposite direction to water flow. The bottle was filled with water sample leaving a gap of about $2 \mathrm{~cm}$ and covered immediately as described by[28]. Immed iately after collection, the samples were labelled and transported to the laboratory in a cooler packed with ice blocks for analysis.

\subsubsection{Sediment Samples}

Sediment samples were collected from the same sampling points where surface water samples were collected using a grab sampler. The sediment sample was scooped from the grab's cup and transferred into sterile sample bottle. The sample was labelled and then transported to the laboratory in a cooler packed with ice blocks for analysis.

\subsubsection{Waste Water Samples}

Waste water samples were collected using the method of[29]. Sterile 2.0 litres sample bottles were used to aseptically draw part of the abattoir waste water. The samples were collected at four different points coded A, B, $\mathrm{C}$ and $\mathrm{D}$ as the waste water was running off the drainage system. About $500 \mathrm{ml}$ of the sample collected from each point were pooled together to get a composite sample. Control samples were collected from water stored in buckets used for washing meat and utensils in the abattoirs. The samples were placed in a cooler containing ice blocks and transported immed iately to the laboratory for analysis.

\subsection{Preparation of Samples}

Sediment and soil samples were processed using the method of[29]. Ten grams of the soil sample was weighed and added to $90 \mathrm{ml}$ of sterile distilled water to get an aliquot, similarly, ten grams of the sediment sample was added to $90 \mathrm{ml}$ of sterile distilled water to get an aliquot. One millilitre of the aliquots, waste water and surface water samples were then serially diluted using the ten-fold serial dilution method as described by[30].

\subsection{Microbi ological Analysis}

\subsubsection{Bacterial Isolates}

From the dilutions of each sample, $0.1 \mathrm{ml}$ aliquot was transferred aseptically into freshly prepared nutrient agar plates and spread evenly on the medium in duplicates. The inoculated plates were incubated at $37^{\circ} \mathrm{C}$ for 24 hours after which plates were examined for growth. Representative colonies of bacteria were picked from different plates after the incubation period. Pure cultures of bacteria were obtained by aseptically streaking representative colonies of different morphological types on to freshly prepared nutrient agar plates. The agar plates were incubated at $37^{\circ} \mathrm{C}$ for 24 hours. Discrete bacterial colonies, which developed on the plates, were used for subsequent characterization tests. Various tests were carried out on the bacterial is olates for possible identification. One millilitre of broth culture of each isolate was used for all the tests. Bacterial isolates were identified in accordance with the schemes of the Bergey's Manual of Determinative Bacteriology[31].

\subsubsection{Fungal Isolates}

Mould isolates which developed on potato dextrose agar and sabouraud's dextrose agar plates were identified using their morphological features followed by microscopic examination of their wet mounts prepared with lactophenolcotton blue and reference made to a fungal identification atlas by[32]. Yeast isolates were also identified using their morphological characteristics, followed by the microscopic examination of their wet mount prepared with normal saline; reference was also made to a fungal identification atlas by[32]. The yeast isolates were further identified using Gram-staining, Sugar fermentation and oxidation and fermentation tests.

\subsection{Adaptation of Hydrocar bon Degrading Isol ates}

Bacterial isolates were adapted for hydrocarbon utilization and degradation using mineral salt broth with crude oil as the sole carbon source. Incubation was at $30^{\circ} \mathrm{C}$ and aerated at 100 strokes per minute[33] for 30minutes each day for 10 days. A loopful of the adapted culture med ium was transferred onto mineral salt agar that contains hydrocarbon as the only carbon source. The plates were incubated at $30^{\circ} \mathrm{C}$ for 5 days after which discrete colonies that developed were transferred onto nutrient agar plates and then incubated at $30^{\circ} \mathrm{C}$ for 24 hours after which they were stored in the refrigerator for further use.

The method described above was also used for fungi isolates though mineral salt medium used was supplemented with streptomycin $(50 \mathrm{mg} / \mathrm{l})$ to suppress bacterial growth[34]. Discrete colonies of the fungi were finally transferred onto SDA slants amended with sterile streptomycin $(50 \mathrm{mg} / \mathrm{ml})$ to suppress bacterial growth as 
described by [34] and then incubated at room temperature for 3-5 days after which they were stored in the refrigerator for further use.

\subsection{Biodegradation Experiment}

The method of [35] was adopted. The experiment was carried out in four (4) stages namely; preparation of inoculums, preparation of chemical reagents, preparation of nutrients and gas chromatographic analysis.

\subsection{Preparation of Inocul ums}

Each of the bacterial isolates which include Pseudomonas sp., Bacilli sp. and Klebsiella sp. were subcultured on a separate fresh, sterile nutrient agar medium followed by incubation at $37^{\circ} \mathrm{C}$ for 24 hours. Likewise, four fungal isolates made up of two mould isolates which include: Aspergillus sp., Penicillium sp. and two yeast isolates, which include: Saccharomyces sp. and Candida sp. were subcultured on sterile potato dextrose broth, followed by incubation at ambient temperature for 3-5 days.

The cells were then harvested by centrifuging at 2000rpm for 30 minutes, after which the cells were individually suspended in sterile physiological normal saline and further washed by centrifuging at $2000 \mathrm{rpm}$ for another 30 minutes to obtain neat cells which were suspended in sterile physiological normal saline and further diluted with sterile physiological normal saline to a low density cell suspension of 0.2 absorbance. The resultant cell suspension was diluted serially, then $0.1 \mathrm{ml}$ from $10^{-2}$ and $10^{-1}$ dilutions for bacteria and fungi, respectively, which served as inoculum was added to the experimental flasks as shown in Table 2 below.

Table 2. Composition of biodegradation experiment cultures

\begin{tabular}{|c|c|}
\hline $\begin{array}{c}\text { Expe rimental } \\
\text { flask No. }\end{array}$ & Composition \\
\hline 1a & $\begin{array}{c}97 \mathrm{ml} \text { mineral salt broth }+3 \mathrm{ml} 3 \% \mathrm{PAH}+0.1 \mathrm{ml} \\
\text { mixed culture of bacteria }\end{array}$ \\
\hline 1b & $\begin{array}{c}97 \mathrm{ml} \text { mineral salt broth }+3 \mathrm{ml} 3 \% \mathrm{PAH}+\mathrm{No} \\
\text { microorganism }(\mathrm{Control})\end{array}$ \\
\hline 2a & $\begin{array}{c}97 \mathrm{ml} \text { mineral salt broth }+3 \mathrm{ml} 3 \% \mathrm{PAH}+0.1 \mathrm{ml} \\
\text { mixed culture of fungi }\end{array}$ \\
\hline 3a & $\begin{array}{c}97 \mathrm{ml} \text { mineral salt broth }+3 \mathrm{ml} 3 \% \mathrm{PAH}+ \\
0.05 \mathrm{ml} \text { mixed culture of bacteria }+0.05 \mathrm{ml} \\
\text { mixed culture of fungi }\end{array}$ \\
\hline
\end{tabular}

\subsection{Preparation of Che mical Reagents}

An ampoule of polycyclic aro matic hydrocarbon (Sig ma, USA) containing $1 \mathrm{mg}$ each of naphthalene, acenaphthylene, acenaphthene, fluorene, phenanthrene, anthracene, fluoranth ene, pyrene, 1,2-Benzanthracene, chrysene, benzo (b)fluoran thene, benzo(k)fluoranthene, benzo (a)pyrene, Ind eno(1,2,3-C.D) pyrene, 1,2,5,6-Dibenzanthracene and 1,12Benzoperylene was aseptically mixed with $99 \mathrm{ml}$ of sterile normal saline (diluents) making $100 \mathrm{ml}$ of stock solution and $0.01 \mathrm{mg}$ or $1 \%$ of individual polycyclic aromatic hydrocarbon constituent. From the stock solution, $3 \mathrm{ml}$ $(0.03 \mathrm{mg} / \mathrm{ml})$ representing $3 \%$ of the stock was used for the experiment.

\subsection{Preparation of Nutrients}

Extracts were stored in borosilicate glass bottles at $4^{\circ} \mathrm{C}$ until analysis which was usually done within 48 hours. Extracts were analyzed using a gas chromatograph (Schimadzu GC-17A gas chromatograph) with flame ionization detector (GC-FID). The GC was equipped with an HP-1 $(30 \mathrm{~m} \times 0.25 \mu \mathrm{m})$ cross-linked methyl siloxane column connected to a split/ split less injector. Operational conditions for analysis were: temperature: injector port, $150{ }^{\circ} \mathrm{C}$; FID, $200{ }^{\circ} \mathrm{C}$ and oven initially $60{ }^{\circ} \mathrm{C}$ and programmed to reach $300^{\circ} \mathrm{C}$ at $20^{\circ} \mathrm{C}$ per min. flow rates for FID glass were; hydrogen $\left(\mathrm{H}_{2}\right), 30 \mathrm{ml} / \mathrm{min}$; air, $300 \mathrm{ml} / \mathrm{mm}$ and nitrogen $\left(\mathrm{N}_{2}\right), 30 \mathrm{ml} / \mathrm{min}$.

\section{Results}

The biodegradation of polycyclic aromatic hydrocarbons (PAHs) by a mixed culture of bacteria after 21 days is shown in Figure 1. From the result, there was a significant difference (ANOVA) in the amount of PAHs remaining after 7 days, 14 days, 21 days (weekly interval). Throughout the duration, the control had the highest and slightly changed amount of PAHs. On the twenty-first day, there was a total detectable loss of PAHs.

Figure 2 shows graphically the result on the biodegradation of polycyclic aro matic hydrocarbons (PAHs) by a mixed culture of fungi at a weekly interval for three weeks. At each interval $\left(7^{\text {th, }} 14^{\text {th }}\right.$ and $21^{\text {st }}$ days $)$, PAHs + mixed fungi culture had lower quantity of PAHs remaining. The control gives the result of a significant difference with each treatment and at each interval as its value remained unchanged throughout the experiment.

Figure 3 shows result on the biodegradation of polycyclic aromatic hydrocarbons (PAHs) by a mixed culture of bacteria and fungi. In all the treatments and intervals, the control had an unchanged quantity of PAHs. There was high significant difference (ANOVA) in the quantity of PAHs remaining after each week. On the seventh day, PAHs + mixed culture of bacteria and fungi treatment had the least quantity of PAHs remaining. At day 21, there was a total loss of PAHs the treatment systems.

Figure 4 shows the effect of time on the biodegradation of polycyclic aromatic hydrocarbons (PAHs) by a mixed culture of bacteria and fungi. There were significant differences in the level of PAHs detected after analysis on weekly intervals. It was equally observed that the level of PAHs decreased as the period of exposure increased except the controls that had equal level of PAHs all through the exposure period ( 7 days to 21 days).

Figure 5 shows the graphical representation of the result on the biodegradation of individual polycyclic aromatic hydrocarbons by a mixed culture of Pseudomonas sp., Bacillus sp. and Klebsiella sp. after 7 days, 14 days and 21 days. The analysis after 7 days revealed the absence of 
naphthalene, acenaphthene, acenaphthylene, fluorine, phenanthrene, anthracene, indeno (1, 2, 3-C.D) pyrene and 1, 2, 5, 6-d ibenzanthracene. However, fluoranthene, pyrene, 1, 2-enzanthracene, chrysene, benzo (b) fluoranthene, benzo (k) fluoranthene, benzo (a) pyrene and 1, 12-benzoperylene had values that ranged between $0.0002 \mathrm{mg} / 1$ to $0.008 \mathrm{mg} / \mathrm{l}$. On the $14^{\text {th }}$ day, benzo $(\mathrm{k})$ fluoranthene and benzo (a) pyrene had values of $0.0004 \mathrm{mg} / 1$ and $0.0005 \mathrm{mg} / 1$, respectively. Analysis after 21 days showed complete absence of all the polycyclic aromatic hydrocarbons (PAHs).

Figure 6 shows the biodegradation of individual polycyclic aromatic hydrocarbon (PAH) by a mixed culture of fungi. On day seven, naphthalene, acenaphthalene, acenaphthylene and fluorine, were completely used by the degrading microorganis ms. During this period, indeno $(1,2$, 3-C.D) pyrene and 1, 2, 5, 6-dibenzanthracene had the highest and lowest values, respectively. Further analys is on day 14, showed that benzo (a) pyrene had the least value of $0.0008 \mathrm{mg} / 1$, and followed by 1, 12-benzoperylene
$(0.0004 \mathrm{mg} / 1)$. Indeno (1, 2, 3-C.D) pyrene and 1, 2, 5, 6-diben zanthracene had $0.002 \mathrm{mg} / 1$ each, while $0.005 \mathrm{mg} / 1$ was detected each for benzo (b) fluoranthene and benzo (k) fluoranthene. On the $21^{\text {st }}$ day, the PAHs were all degraded except indeno (1, 2, 3-C.D) pyrene and 1, 2, 5, 6-diben zanthracene that each had value of $0.0009 \mathrm{mg} / 1$.

The results of the biodegradation of individual polycyclic aromatic hydrocarbons by a mixed culture of bacteria (Pseudomonas sp., Bacillus sp., Klebsiella sp.) and fungi (Aspergillus sp., Penicillium sp., Saccharomyces sp. and Candida sp.) for days 7, 14 and 21 are shown in Figure 7. From the result, naphthal ene, acen aphthalene, acenaphthylene, fluorine, 1, 2, 5, 6-dibenzanthracene and 1, 2-benzoperylene only were comp letely degraded.

Analysis on the $14^{\text {th }}$ day indicates that all the PAHs except benzo (b) fluoranthene, benzo (k) fluoranthene, benzo (a) pyrene and indeno (1, 2, 3-C.D) pyrene were detected, while on the $21^{\text {st }}$ day 1 , 12-benzoperylene only was detected while others were completely degraded.

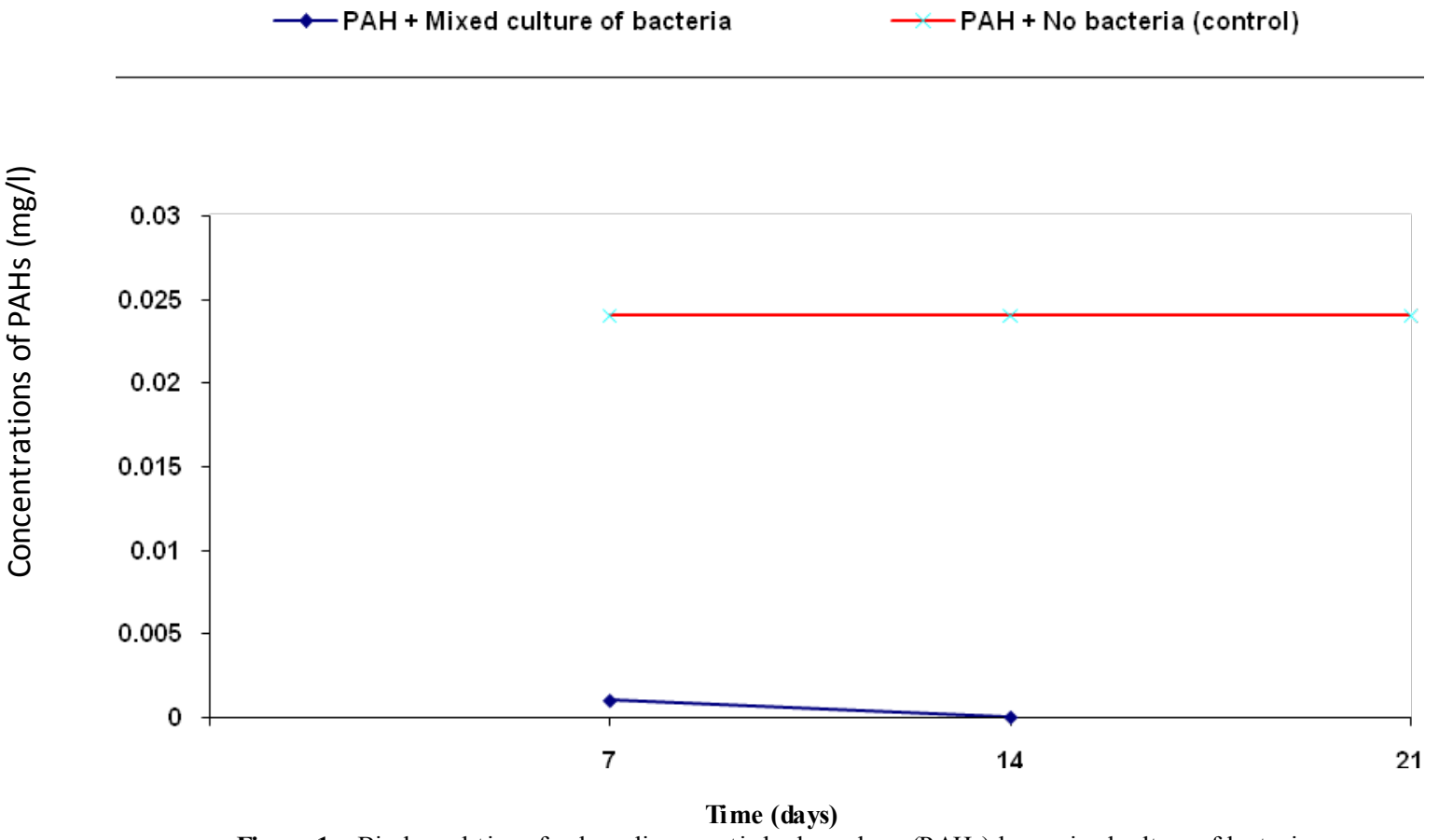

Figure 1. Biodegradation of polycyclic aromatic hydrocarbons (PAHs) by a mixed culture of bacteria 


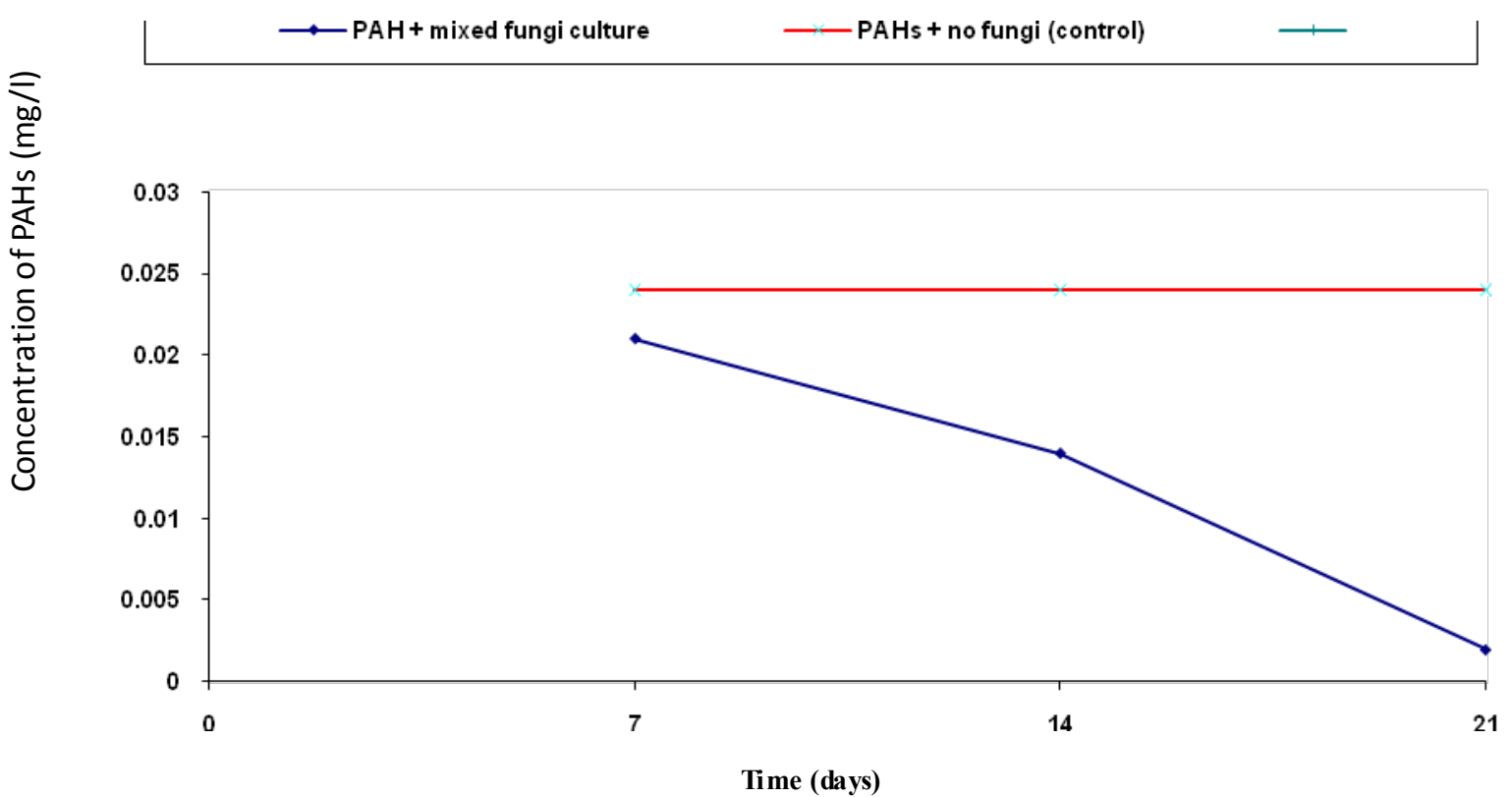

Figure 2. Biodegradation of polycyclic aromatic hydrocarbons (PAHs) by a mixed culture of fungi and in combination with NPK fertilizer and cow dung

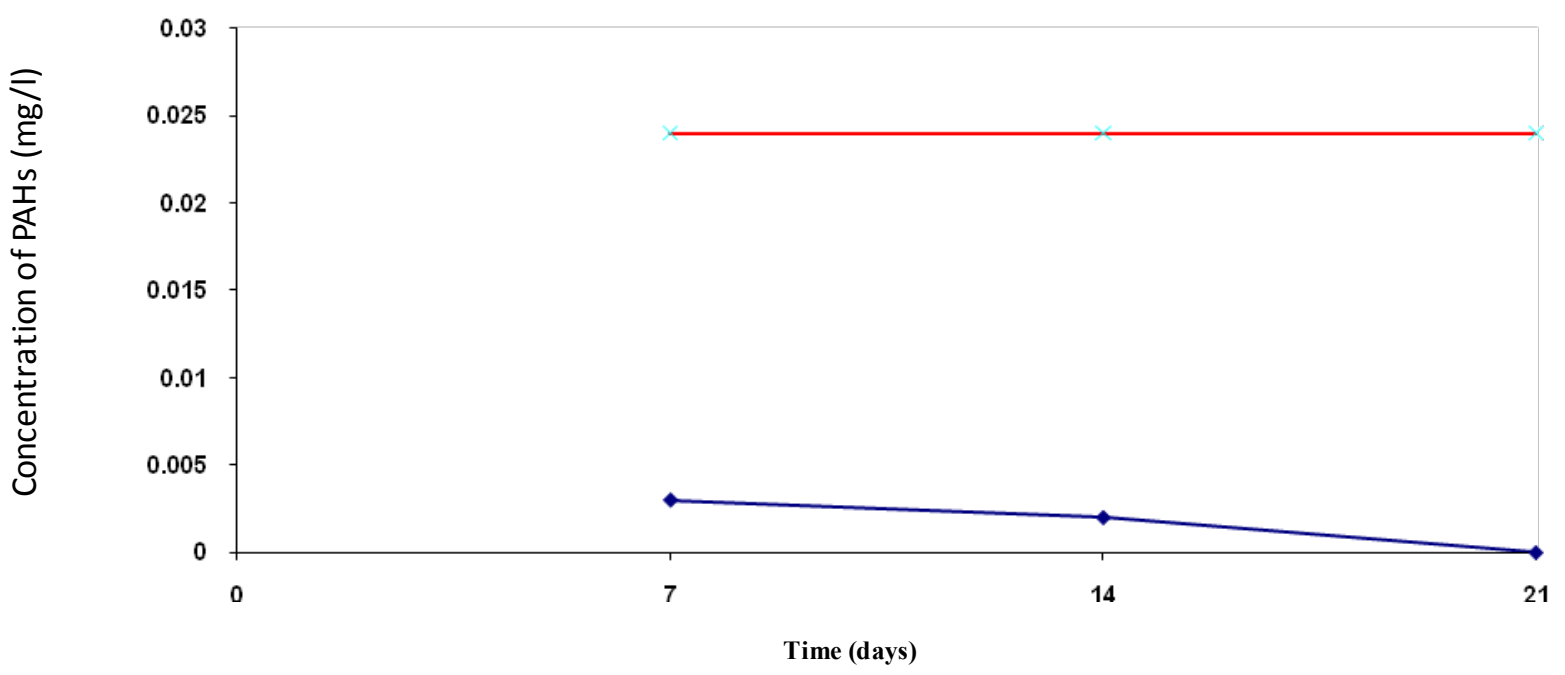

Figure 3. Biodegradation of polycyclic aromat ic hydrocarbons (PAHs) by a mixed culture of bacteria and fungi and in combination with NPK fertilizer and cow dung 


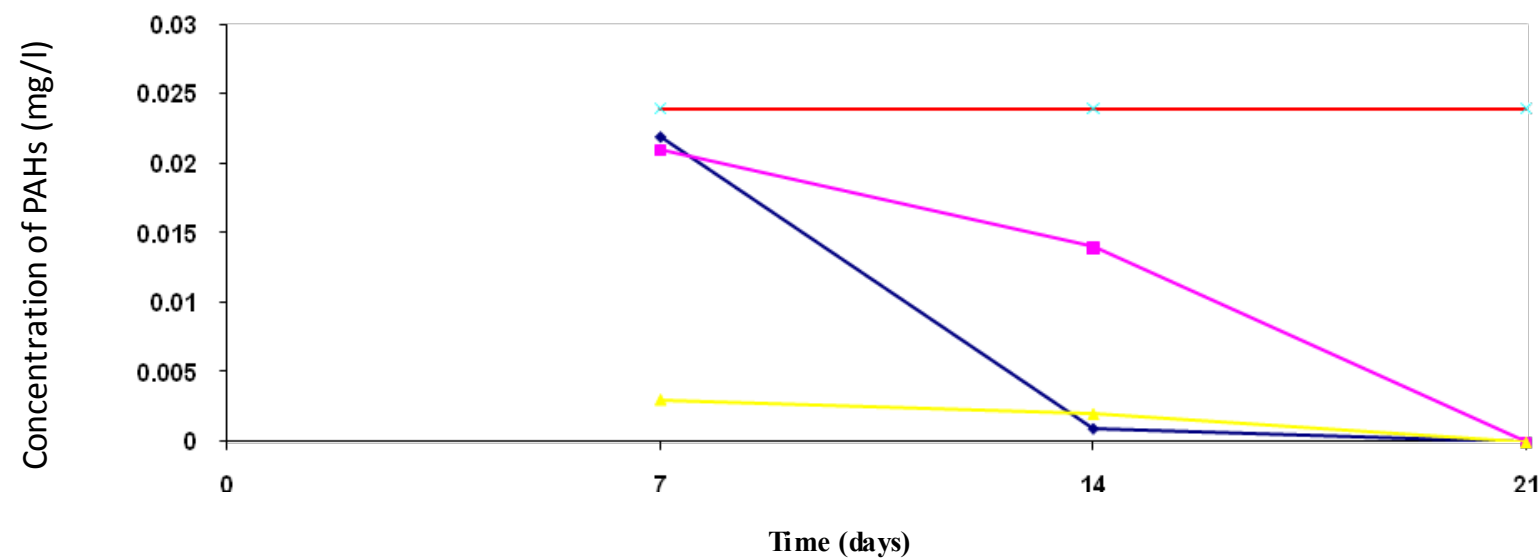

Figure 4. Effect of time on the biodegradation of polycyclic aromatic hydrocarbons by mixed cultures of bacteria and fungi

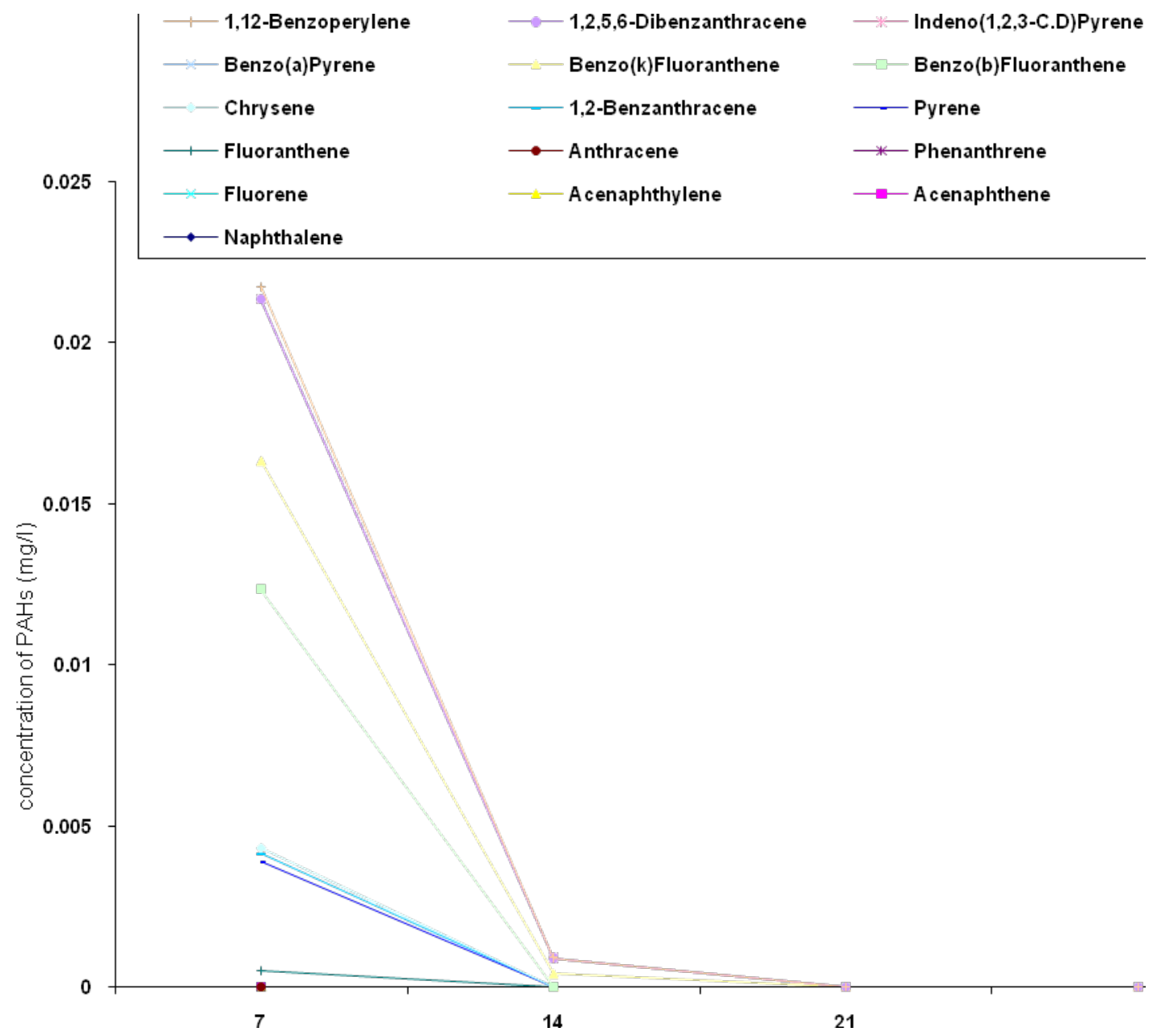

Figure 5. Biodegradation of individual polycyclic aromatic hydrocarbons by a mixed culture of bacteria (Pseudomonas sp., Bacillus sp. and Klebsiella sp.) 

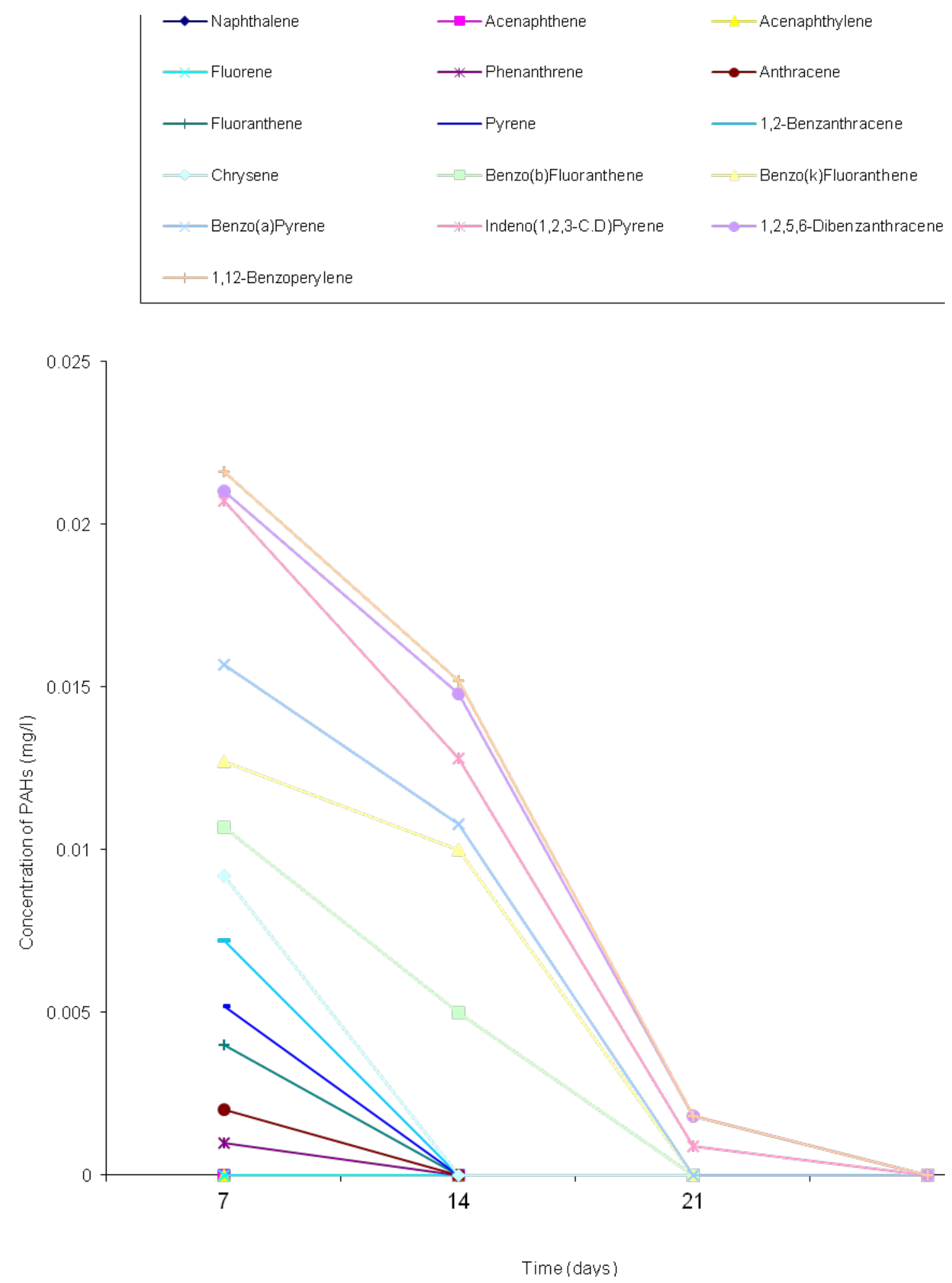

Figure 6. Biodegradation of individual polycyclic aromatic hydrocarbon by a mixed culture of fungi (Aspergillus sp., Penicillium sp., Saccharomyces sp. and Candida sp.) 

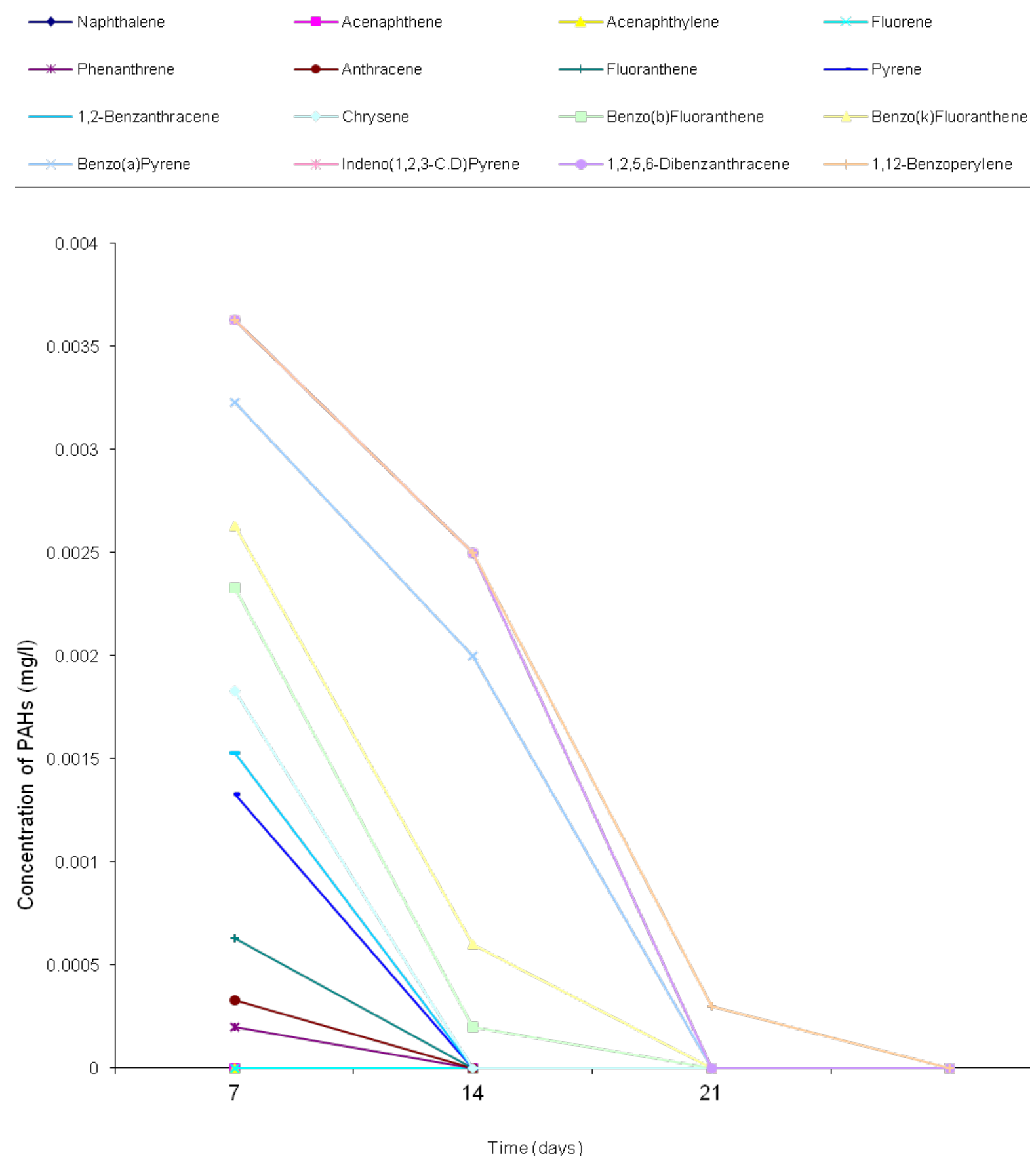

Figure 7. Biodegradation of individual polycyclic aromatic hydrocarbon by a mixed culture of bacteria (Pseudomonas sp., Bacillus sp. and Klebsiella sp.) and fungi (Aspergillus sp., Penicillium sp., Saccharomyces sp. and Candida sp.)

\section{Discussion}

Mixed cultures of bacteria like Pseudomonas sp, Bacillus $\mathrm{sp}$ and Klebsiella sp and fungi such as Aspergillus sp, Penicillium $\mathrm{sp}$, Saccharomyces $\mathrm{sp}$ and Candida $\mathrm{sp}$ were used for the biodegradation test. Although some PAHs are toxic, carcinogenic and teratogenic; it was reported by[36] that a variety of bacteria can degrade certain PAHs completely to $\mathrm{CO}_{2}$ and metabolic intermediates, en route gaining energy and carbon for cell growth.

The biodegradation tests results showed slight drop in the initial concentration of the polycyclic aromatic hydrocarbons (PAHs) used as control. This could be as a result of the failure of the extractant to extract all the PAHs added. The treatment (PAHs + mixed culture of bacteria) had the least quantity of PAHs remaining; this could be as a result of the failure of the extractant to extract all the PAHs added to the treatment. Lowest concentration of PAHs detected on day 7 (Figure 3) for PAHs + mixed culture of bacteria and fungi treatment could be as a result of experimental error. Figure 4 indicated that with the exception of the control, the concentrations of polycyclic 
aromatic hydrocarbons (PAHs) decreased with increase in exposure time. This implies that the concentration of PAHs used in the study was not toxic to the degrading microorganis ms. Based on this, the organisms constantly utilized the substrate (PAHs) throughout the duration of the experiment.

The observations in Figs. 5 to 7 indicate that in most cases, low molecular weight PAHs were absent indicating degradation. This observation corroborates the report by [37] that there is preferential attack on less complex aromatic molecules. It was also reported[22] that those PAHs with 2 or 3 rings e.g. naphthalene, anthracenes are more biodegradable. The high molecular weight polycyclic aromatic hydrocarbons were observed not to be easily degraded in most cases after the $7^{\text {th }}$ day and $14^{\text {th }}$ day except on the $21^{\text {st }}$ day. This is because the environmental fate of a polycyclic aromatic hydrocarbon (PAH) particle is dependent in part on both its molecular size i.e. the number of aromatic rings and patterns of ring linkages[16]. Also [16] reported that increase in the size and angularity of a $\mathrm{PAH}$ molecule results in a concomitant increase in hydrophobicity and electrochemical stability. The observation was further supported by[22] that PAH molecule stability and hydrophobicity are two primary factors that contribute to the persistence of high molecular weight PAHs in the environment.

However, comparing the degradation efficiency of bacteria and fungi mixed cultures on polycyclic aromatic hydrocarbons (PAHs), it is evident from this study that no definite pattern was established. This then indicates that both bacteria and fungi isolates used for the study possess similar enzy matic capability to degrade polycyclic aromat ic hydrocarbons (PAHs). However bacteria are more efficient biodegraders than fungi. The trend observed in this study is in contrast with that of [35] who observed that fungi have a greater capacity and enzymatic capability to degrade polycyclic aromatic hydrocarbons (PAHs) than bacteria. However, some researchers [15, 38 - 40] have reported that fungi are good PAH degraders while others[41 - 44] have reported that bacteria are good degraders of polycyclic aromatic hydrocarbons (PAHs).

The treatment with mixed cultures of microorganisms was found better than single treatment where only bacteria or fungi species are used singly.

\section{Conclusions}

Although abattoir operation could be very beneficial to man because it provides meat for human consumption and other useful by-products, still, it can be very hazardous to public health with respect to the wastes that is generated. The high pollution strength of the abattoir wastes as revealed in this study further confirmed the danger associated with discharging untreated wastes to the environment, hence the need for adequate treatment to ensure decontamination.
There is no doubt that the pollution caused by abattoir wastes is a clear evidence that the meat processing industry mostly in developing countries like Nigeria has a potential for generating large quantities of waste. The study indicated negative impact of abattoir activities on the soil.

Based on the foregoing, the abattoir management system should include a waste management plan designed for abattoir operations. Legis lative measures are also necessary, laws and rules on land use and waste regulation to control the location and management of abattoirs should be made.

Phytoremediation of PAHs in polluted soils with special reference to carcinogenic types should be encouraged.

There is also need for active research into the waste and pollution minimization strategies, waste avoidance technologies, cleaner production processes and zero polycyclic aromatic emission concepts in Nigeria.

A population-based immunochemical survey to determine the level and effect of polycyclic aromatic hydrocarbons among abattoir workers should be undertaken by health agencies since these group of chemicals are known to have toxic, mutagenic, teratogenic and carcinogenic effects on humans.

\section{REFERENCES}

[1] Amanchukwu, SC., Obafemi, A. Okpokwasili, GC. (1989). Hydrocarbon degradation and utilization by a palmwine yeast isolate. FEMS Microbiol. Lett. 57:151-154.

[2] Odokuma, LO., Dickson, AA. (2003). Bioremediation of a crude oil polluted tropical rain forest soil. Global J. Environ. Sci. 2(1): 29-40.

[3] Jones, IG., Rowth, M. (1996). An outbreak of Escherichia coli 0157 and campylobacteriosis associated with contamination of a drinking water supply. Public Health. 110: 282 .

[4] Nadeau, RR., Singhvi, J., Ryabik, Y., Lin, J., Syslo, J. (1993). Monitoring bioremediation for bioremediation efficacy. The Marrow Marsh experience. Proceedings of the 1993 Oil Spill Conference. American petroleum Institute, Washington, D.C., pp. 477-485.

[5] Obire, O. (1988). Studies on the biodegradation potential of some microorganisms isolated from water systems of two petroleum-producing areas in Nigeria. Nig. J. Botany. 1: 81-90.

[6] Kanaly, R A., Harayama, S. (2000). Biodegradation of high molecular weight polycyclic aromatic hydrocarbons by bacteria. J. Bacteriol. 182: 2059-2067.

[7] Barkay, T., Navon-Venezia, S., Ron, EZ., Rosenberg, E. (1999). Enhancement of solubilization and biodegradation of PAHs by bioemulsifier. Appl. Environ. Microbiol. 65: 2697-2702.

[8] Duke, NC., Burns, KA., Swannel, RPJ., Dalhaus, O., Rupp, RJ. (2000). Dispersant use and a bioremediation strategy as alternate means of reducing impacts of large oil spills on man grove: The Gladstone Field Trials. Mar. Pollut. Bull. 41: 
403-412.

[9] Bogan, BW., Trbovic, V., Paterek, JR. (2003). Incusion of vegetable oils in Fenton's chemistry for remediation of PAH-contaminated soils. Chemosphere. 50: 15-21.

[10] Cerniglia, CE. (1993). Biodegradation of polycyclic aromatic hydrocarbons. Curr. Opin. Biotechnol. 4: 331-338.

[11] Nwachukwu, MI. (2010). Biophysical properties of abattoir wastes and biodegradation of Polycyclic Aromatic Hydrocarbonsby associated microorganisms. Ph.D. Thesis Rivers State University of Science and Technology, pp $1-210$

[12] Wilson, SC., Jones, KC. (1993). Bioremediation of soil contaminated with polynuclear aromatic hydrocarbons (PAHs). A Review. Environ. Pollut. 81: 229-249.

[13] McElroy, AE., Farrington, JW., Teal, JM. (1989). Degradation of PAHs by microorganisms. Appl. Environ. Microbiol. 55: 269-274.

[14] Cho, JC., Kim, SJ. (1997). Biodegradation of phenanthrene in soil microcosms. In: Int. In-situ and On-site Bioremediation Symp. New Orleans. Pp. 105-110.

[15] Cerniglia, CE. (1992). Biodegradation of PAHs. Biodegrad. 3: 351- 368 .

[16] Harms, H., Bosman, TNP. (1997). Mass transfer limitation of microbial growth and pollutant degradation. J. Indust. Microbiol. Biotech. 18: 97-105.

[17] Hughes, JB., Beckles, DM., Chandra, SD., Ward, CH. (1997). Utilization of bioremediation for the treatment of PAH-contaminated sediments. J. Ind. Microbiol. Biotech. 18: $152-160$.

[18] Bouchez, M., Blanchet, D., Vandecas-Teele, JP. (1995). Degradation of polycyclic aromatic hydrocarbons by pure strain and by defined strain association: Inhibition phenomena and co-metabolism. Appl. Microbiol. Biotechnol. 43: 156-164.

[19] Bauer, JE., Capone, DG. (1988). Effects of co-occuring aromatic hydrocarbons on degradation of individual poly cy clic aromatic hydrocarbons. Appl. Environ. Microbiol. 54: $1649-1655$.

[20] Foght, JM., Gutnick, DL., Westlake, DWS. (1989). Effect of emulsion on biodegradation of crude oil in pure and mixed cultures. Appl. Environ. Microbiol. 55: 36-42.

[21] Mueller, JG., Chapman, PJ., Pritchard, PH. (1989). Action of a fluoranthene-utilizing bacterial community on polycyclic aromatic hydrocarbon components of creosote. Appl. Environ. Microbiol. 55: 1504-1506.

[22] Park, KS., Sims, RS., Dupont, RR., Doucette, WJ., Mathews, JE. (1990). Fate of polycyclic aromatic hydrocarbon compounds in two soil types: Influence of volatilization, abiotic loss and biological activity. Environ. Toxicol. Chem. 9: 187-195.

[23] Leahy, GJ., Colwell, RR (1990). Microbial degradation of hydrocarbon in the environment. Microbiol. Rev. 54(3): 303-315.

[24] Dibble, JT., Bartha, R. (1985). Effect of environmental parameters on the biodegradation of oil sludge. Appl. Environ. Microbiol. 37: 729-739.
[25] Michael, JW., Neil, LM., John, SR., Gary, H. (2001). Industrial Microbiology: An Introduction. $1^{\text {st }}$ ed. Blackwell publishing Company London. Pp. 229-321.

[26] Ekundayo, EO., Obuekwe, CO. (1997). Effects of an oil spill on soil physico-chemical properties of a spill site in a typical paleudult of Midwestern Nigeria. Environ. Monit. Assess. 45: 209-221.

[27] Odokuma, LO., Okpokwasili, GC. (1993). Seasonal influences on inorganic anion monitoring of the New Calabar River, Nigeria. Environ. Manage. 17(4): 491-496.

[28] Onyeagba, RA., Umeham, SN. (2004). Analytical Methods in Water Microbiology. In: Onyeagba, R.A. (ed.). Laboratory Guide for Microbiology. $1^{\text {st }}$ ed. Crystal Publishers Okigwe, Nigeria. Pp. 178-191.

[29] Adesemoye, AO., Opere, BO., Makinde, SCO. (2006). Microbial content of abattoir waste water and its contaminated soil in Lagos, Nigeria. Afr. J. Biotechnol. 5(20): 1963-1968.

[30] Prescott, LM., Harley, JP., Klein, DA. (2005). Microbiology. $6^{\text {th }}$ ed. McGraw Hill, London. Pp. 135-140.

[31] Holt, JG; Kreig, N; Sneath, PAH and Williams, S T (1994). Bergey's Manual of Determinatve Bacteriology. $9^{\text {th }}$ ed ition. Williams and Wilkins Co., Baltimore, USA.

[32] Barnett, HL. Hunter, BB. (1972). Illustrated Genera of Imperfect Fungi. $3^{\text {rd }}$ ed. Burgess publishing company, Minnesota, USA.

[33] Wang, W. (1984). Response of Nitrobacter sp. to toxicity. Environ. Int. $10: 21-26$

[34] Okerentugba, PO., Ezeronye, OU. (2003). Petroleumdegrading potentials of single and mixed microbial cultures isolated from rivers and refinery effluents in Nigeria. Afr. $J$. Biotechnol. 2(9): 288-292.

[35] Okoro, CC (2008). Biodegradation of hydrocarbons in untreated produce water using pure fungal cultures. Afr. $J$. Microbiol. Res. 2: 217-223.

[36] Hedlund, BP., Geiselbrecht, AD., Bair, TJ, Staley, JT. (1999). Polycyclic aromatic hydrocarbons degradation by a new marine bacterium, Neptunomonas sp. Appl. Environ. Microbiol. 65(1): 251-259.

[37] Rothermich,MM., Hayes, LA., Lovley, DR. (2002). Anaerobic, sulphate-dependent degradation of polycyclic aromatic hydrocarbons in petroleum-contaminated habour sediment. Environ. Sci. Technol. 36: 4811-4817.

[38] Andrea, RC., Tania, AA, Lucia, RD. (2001). Biodegradation of polycyclic aromatic hydrocarbons by soil fungi. Braz. J. Microbiol. 32(4) : 124-129.

[39] Gadd, GM (2001). Fungi in Bioremediation. Cambridge University Press, Cambridge. P. 220

[40] Sutherland, JB (2004). Degradation of hydrocarbons by yeast and filamentous fungi. Fungial Biotechnology in Agricultural Food and Environmental Application. Arora, D.K(ed). Marcel Dekker Inc., USA. P. 324.

[41] Haritash, AK., Kalushik, CP (2009). Biodegradation aspects of polycyclic aromatic hydrocarbons (PAHs): A review. $J$. Hazard. Mat. 169: 1-15 
[42] Hamamura, N., Olson, SH., Ward, DM, Inskeep, WP (2006). Microbial population dynamics associated with crude oil biodegradation in diverse soil. Appl. Environ. Microbiol. 72(9): 6316-6324.

[43] Foght, JM, Westlake, DWS (1988). Degradation of polycyclic aromatic hydrocarbons (PAHs) and aromatic heterocycles by a Pseudomonas sp. Can. J. Microbiol. 34: $1135-1141$

[44] Okpokwasili, GC., Sommerville, CC., Sullivan, M., Grimes, DJ., Colwell, RR. (1986). Plasmid-mediated degradation of hydrocarbons in estuarine bacteria. Oil Chem. Pollut. 3:177-129. 